\section{ABSTRACT AND MEETING INFORMATION}

Abstracts should be typed on plain white paper, single spaced, no longer than 250 words, with twoinch top and bottom margins, and 2 1/8-inch side margins. The abstract should be headed with title, author names with degrees and institution, city and state with an asterisk next to the presenting author. This is to be followed with the objectives, methods, results and conclusions of the research. Abstracts will be printed exactly as received. Abstract and four copies should be mailed with presenting author's address and telephone number to: Bloodborne Pathogen Conference, HIV Infections Branch, Hospital Infections Program, Centers for Disease
Control and Prevention, Mailstop A- 07, Atlanta, GA 30333. Deadline for receiving abstracts is October 31, 1993.

For hotel information and registration forms, contact John I? Lynch, Organization Department, American College of Surgeons, 55 E. Erie St., Chicago, IL 60011-2797.

Telephone (312) 664-4050.

\title{
SHEA Annual Luncheon
}

The Society for Hospital Epidemiology of America will host its annual luncheon during the Interscience Conference on Antimicrobial Agents and Chemotherapy (ICAAC) in New Orleans, Louisiana, at the Hilton Riverside and Towers on Tuesday, October 19, 1993 from 12:00 EM. to 2:00 EM. The featured luncheon speaker will be Michael I?
Osterholm, $\mathrm{PhD}, \mathrm{MPH}$, state epidemiologist in the Minnesota Department of Health. The title of his talk is "Partners in Pump Handles." Also featured at this luncheon will be an update of SHEA's activities. Come to the luncheon and bring a guest. Nonmembers are welcome. The cost for SHEA members preregistered by September 18,
1993 is $\$ 30$ and the cost for nonmembers is $\$ 35$ if preregistered by the same date. The cost for registration after September 18 is $\$ 40$. To register for the luncheon, write to: SHEA Annual Luncheon, 875 Kings Highway, Suite 200, Woodbury, NJ 08096. Telephone (609) 845-1636; FAX (609) 853-0411.

\section{$E$ coli O157:H7}

At the May 1993 meeting of the American Society for Microbiology, Joy G. Wells and Patricia M. Griffin, MD, gave a presentation on the simplicity of screening stool samples from patients with bloody diarrhea for the presence of Escherichia coli O157:H7 by determining whether there are sorbitol-negative enteric organisms present. In Ms. Wells' experience, more than $95 \%$ of sorbitol-negative E coli 0157 were confirmed to be 0157:H7.

Dr. Griffin pointed out that clinical laboratories screening for this strain of E coli can help departments of public health in identifying clusters of this pathogen before rather than after a major outbreak of clinical disease is noted (as recently occurred at a restaurant chain in the Pacific Northwest).
Although there is no recognized effective antibiotic therapy for symptomatic or asymptomatic E coli $\mathrm{O} 157: \mathrm{H} 7$ infection, identification of this strain may help clinicians clarify the etiology of some episodes of severe bloody diarrhea and be aware of the possible development of the hemolytic uremic syndrome in their patients.

It may be useful to call this important, relatively simple screen to the attention of your clinical microbiologist. We would suggest that you also consider providing your laboratory with an

Brief items of interest for the SHEA N ews or Newsletter may be sent to C. Glen Mayhall, M D, SHEA, N ewsletter Editor, Division of Infectious Diseases, D epartment of M edicine, U niversity of Tennessee, M emphis, 956 Court A ue., M emphis, TN 38163; FAX (901) 528-5854. Copy should be typed, double-spaced, and should not exceed five pages. 